\title{
Effect of Priming, Biofertilizers and Nitrogen Levels on Yield and Nutrient Uptake by Wheat
}

\author{
Bishnupriya Patra* and Jagdev Singh \\ Department of Agronomy, CCS Haryana Agricultural University, Hisar, India \\ *Corresponding author
}

\begin{tabular}{|c|c|}
\hline & A B S T R A C T \\
\hline Keywords & \multirow{4}{*}{$\begin{array}{l}\text { A field experiment was conducted during rabi season } 2015-16 \text { at research farm of } \\
\text { CCSHAU, Hisar to study the impact of priming, biofertilizers with different nitrogen } \\
\text { levels on growth, yield and nutrient uptake of late sown wheat. The experiment comprised } \\
\text { of } 5 \text { treatments i.e. no seed priming, seed priming with water, seed priming with water + } \\
\text { Azotobacter, seed priming with water + AM fungi, seed priming with water + Biomix in } \\
\text { main plot and } 4 \text { nitrogen levels viz. } 120,135,150,165 \mathrm{~kg} \mathrm{ha}^{-1} \text { in sub plot was carried out } \\
\text { in split plot design with three replications. Priming with biofertiliser inoculations } \\
\text { significantly improve yield and nutrient uptake. Yield and nutrient uptake is highest at } \\
\text { biomix treated plot than others. The growth and yield and nutrient uptake showed an } \\
\text { increase with increase in nitrogen dose up to } 150 \mathrm{~kg} \mathrm{ha}^{-1} \text {. }\end{array}$} \\
\hline $\begin{array}{l}\text { Late sown wheat, seed } \\
\text { priming, Azotobacter, } \\
\text { AM fungi, Biomix, } \\
\text { yields, Nutrient uptake }\end{array}$ & \\
\hline Article Info & \\
\hline $\begin{array}{l}\text { Accepted: } \\
\text { 10 June } 2018 \\
\text { Available Online: } \\
10 \text { July } 2018\end{array}$ & \\
\hline
\end{tabular}

\section{Introduction}

Wheat is an annual plant of gramineae family. It contains $12 \%$ proteins which is more than other cereals. It is world's leading cereal crop, cultivated in an area about 215.26 million ha with a production of 584.76 million tones. Under late sowing, the yield reduction is principally due to delayed germination, insufficient seedling emergence and inappropriate stand establishment because of low temperature prevailing at sowing time. Pre-germinated seeds and seed priming is helpful in early germination and reducing the risk of poor stand establishment which also improves nutrient uptake.
For a sustainable agriculture, it is imperative to utilize renewable inputs which can maximize the ecological benefits and minimize the environmental hazards. One possible way of achieving this is to decrease dependence on use of chemical nitrogen fertilizers by harvesting the atmospheric nitrogen through biological processes (Kachroo and Razdan, 2006).

Biofertilizers play a very significant role in improving soil fertility by fixing atmospheric nitrogen, both, in association with plant roots and without it, solubilise insoluble soil phosphates and produces plant growth substances in the soil. 
They are in fact being promoted to harvest the naturally available, biological system of nutrient mobilization (9). An integrated approach for use of biofertilizers with chemical fertilizers is considered as the need of hour, as biofertilizers are not replacement of fertilizers but can supplement their requirement. Thus in this investigation all factors combined in all possible combinations to improvise the yield of late sown of wheat and nutrient uptake.

\section{Materials and Methods}

A field experiment conducted during rabi 2015-16 at Research Farm of Department of Agronomy, Chaudhary Charan Singh Haryana Agricultural University, Hisar, Haryana (India). The important soil properties of the field were: $\mathrm{pH} 8.3$, organic carbon $0.32 \%$, EC $0.30 \mathrm{dSm}^{-1}$, available N $161 \mathrm{~kg} / \mathrm{ha}$, available P $13 \mathrm{~kg} / \mathrm{ha}$ and available K $356 \mathrm{~kg} / \mathrm{ha}$. Treatments consisted of no seed priming, seed priming with water, seed priming with water + Azotobacter, seed priming with water $+\mathrm{AM}$ fungi, seed priming with water + Biomix, 4 nitrogen levels in sub plots $(120,135,150,165$ $\mathrm{kg} \mathrm{N} \mathrm{ha}{ }^{-1}$ ). These treatment combinations were replicated thrice in a split plot design having priming and biofertiizers in main plots and nitrogen in sub-plots.

Wheat seeds were primed and inoculated with biofertilizers as per treatments. Recommended doses of $\mathrm{P}$ and $\mathrm{K}$ were applied through single superphosphate and muriate of potash, respectively. The wheat variety $\mathrm{WH} 1124$ was sown on $29^{\text {th }}$ December with $100 \mathrm{~kg}$ seed/ha. Appropriate management practices were adopted to raise the crop. Grain and straw yields were recorded at harvest of the crop. NPK content in grain and straw at harvest was determined. For analysis of NPK oven dried plant material (grain and straw at harvest) from each plot was grinded separately with grinder. Nitrogen (Nessler's reagent method, Lindner, 1944), phosphorus (Vanadomolybdo- phosphoric acid yellow colour method, Jackson, 1973) and potassium (Flame photometer method, Richards, 1954) contents in sample were analyzed.

The uptake of each nutrient was computed as:

Nutrient uptake by grain $\left(\mathrm{kg} \mathrm{ha}^{-1}\right)=$

Nutrient content in grain (\%) x Grain yield (kg ha $\left.^{-1}\right)$ Nutrient

100

Nutrient uptake by straw $\left(\mathrm{kg} \mathrm{ha}^{-1}\right)=$

Nutrient content in straw $(\%) \times$ Straw yield $\left(\mathrm{kg} \mathrm{ha}^{-1}\right)$

100

\section{Results and Discussion}

\section{Yield studies}

The results revealed that there was an increase of 9.5, 8.6, 6.1 and $2.7 \%$ in grain yield with water priming of seed + Biomix, priming + $\mathrm{AM}$, priming + Azotobacter and water priming of seed over unprimed, uninoculated treatment respectively. This increase in grain yield is due to the fact that there is positive correlation of the yield attributes with grain yield and yield attributes increased with biofertilizer inoculations thus yield also improved. The corresponding increase were 7.4, 6.6, 6.2 and $2.8 \%$ for straw yield and 8.2, 7.4, 6.4 and $2.8 \%$ for biological yield. These findings are in conformity with the results of Behl et al., (2003) for AM fungi; Milosevic et al., (2012) and Narula et al., (2005) for Azotobacter; Bahrani et al., (2010) for Azotobacter and Mycorrhiza and Saber et al., (2012), Singhal et al., (2012) for PSB in wheat. Harvest index slightly improved with biofertilizer treatments but remained statistically non-significant. This might be on account of almost similar pattern 
of increase in grain and straw yield and consequently biological yields under all the inoculation treatments. Similar results were reported by Jakhar (2004).

Grain, straw and biological yields were improved significantly with increase in $\mathrm{N}$ dose up to $150 \mathrm{~kg} \mathrm{ha}^{-1}$ which was statistically at par with $165 \mathrm{~kg} \mathrm{~N}$ dose (Table 1). There was an increase of $4.5,8.2$ and $11.3 \%$ with 135,150 and $165 \mathrm{~kg} \mathrm{~N} \mathrm{ha}^{-1}$ over $120 \mathrm{~kg} \mathrm{ha}^{-1}$. The higher grain yield obtained with increasing nitrogen levels could be ascribed to its favorable effect on yield attributing characters. Increase in straw and biological yields of wheat with successive increase in $\mathrm{N}$ levels probably came through favorable influence of increasing $\mathrm{N}$ levels on growth parameters in terms of plant height, number of tillers, dry matter production and LAI. Corroborative findings have been reported by Beheraa and Rautaray (2010), Patel et al., (2012); Pandey et al., (2014), Kaur et al., (2016); Narolia et al., (2016), Nishant et al., (2016) in wheat crop.

\section{Nutrient concentration and uptake}

The nitrogen contents of grain and straw (Table 2) were not significantly affected by the different treatments of seed priming with water and biofertilizer inoculations.

The nitrogen fixed by biofertilizers was utilized by the crop for producing higher dry matter and grain yield (Table 1) as compared to uninoculated treatment. Thus, the accumulation of nitrogen under biofertilizer inoculated plants at harvest was not substantial compared to uninoculated treatment. Similar findings were also reported by Jakhar (2004). However, other nutrients ( $\mathrm{P}, \mathrm{K}$ contents) were not influenced significantly by water priming with biofertilizer inoculations both in grain and straw. Similar results were reported by Suri and Choudhary (2010) for phosphorus and Jakhar (2004) for phosphorus and potassium. Nutrient contents were in a increasing trend up to priming with biomix except $\mathrm{P}$ content in straw, where $\mathrm{P}$ content in AM fungi treatment is higher than biomix as nutrient taken is diluted due to more grain yield in case of biomix than AM fungi (Table 2).

In case of nitrogen uptake by grain and straw, total uptake was not affected by seed priming with water significantly, but biofertilizer inoculations gave significantly higher $\mathrm{N}$ uptake by grain and total uptake. Similar results were reported by Kader et al., (2002), Singh et al., (2013), Pandey et al., (2014) Narolia et al., (2016), Nishant et al., (2016). However, Azotobacter was at par with seed priming with water (Table 3 ) but significantly better as compared to no inoculation treatment. Whereas, $\mathrm{N}$ uptake by straw under seed priming with water and biofertilizer inoculations are statistically at par. Priming had no effect in improving uptake of $\mathrm{P}$ and $\mathrm{K}$ but biofertilizer inoculations significantly increased the $\mathrm{P}$ uptake except Azotobacter which was at par with priming with water (Table 3). Similar findings were reported by Sushila and Giri (2000) for phosphorus and Gupta (2002) for potassium.

Nitrogen content improved significantly with each successive increment of $\mathrm{N}$ levels (135, $150,165 \mathrm{~kg} \mathrm{~N} \mathrm{ha}^{-1}$ ) which enhanced $\mathrm{N}$ uptake in grain as well as straw significantly over lower level $\left(120 \mathrm{~kg} \mathrm{ha}^{-1}\right)$ however, two higher nitrogen levels were statistically at par in case of straw (Table 2).

Total $\mathrm{N}$ uptake was significantly increased with each increment in nitrogen dose up to $165 \mathrm{~kg} \mathrm{ha}^{-1}$. This was mainly due to increase in $\mathrm{N}$ content as well as higher grain and straw yield with increasing N levels. Similar results were reported by Kader et al., (2002), Singh $e t$ al., (2013), Pandey et al., (2014) Narolia et al., (2016), Nishant et al., (2016). 
Table.1 Effect of seed priming, biofertilizer inoculations and nitrogen levels on yield of wheat

\begin{tabular}{|c|c|c|c|}
\hline Treatment & $\begin{array}{l}\text { Grain yield } \\
\quad\left(\mathbf{q} \mathbf{h a}^{-1}\right)\end{array}$ & $\begin{array}{c}\text { Straw yield } \\
\quad\left(\mathbf{q} \mathbf{h a}^{-1}\right)\end{array}$ & $\begin{array}{l}\text { Biological yield } \\
\left(\mathrm{q} \mathrm{ha} \mathbf{h}^{-1}\right)\end{array}$ \\
\hline \multicolumn{4}{|l|}{ Seed priming and inoculation } \\
\hline No seed priming & 36.50 & 56.10 & 92.60 \\
\hline Seed priming with water & 37.49 & 57.70 & 95.19 \\
\hline $\begin{array}{l}\text { Seed priming + Inoculation with } \\
\text { Azotobacter }\end{array}$ & 38.73 & 59.57 & 98.50 \\
\hline Seed priming + Inoculation with AM fungi & 39.64 & 59.82 & 99.46 \\
\hline Seed priming + Inoculation with Biomix & 39.97 & 60.26 & 100.23 \\
\hline SEm \pm & 0.66 & 0.86 & 0.94 \\
\hline CD at $5 \%$ & 2.14 & 2.80 & 3.07 \\
\hline \multicolumn{4}{|l|}{ Nitrogen level (kg ha $\left.{ }^{-1}\right)$} \\
\hline 120 & 36.29 & 55.65 & 91.94 \\
\hline 135 & 37.92 & 57.76 & 95.68 \\
\hline 150 & 39.26 & 60.33 & 99.59 \\
\hline 165 & 40.39 & 61.03 & 101.42 \\
\hline SEm \pm & 0.42 & 0.61 & 0.77 \\
\hline CD at $5 \%$ & 1.21 & 1.76 & 2.22 \\
\hline
\end{tabular}

Table.2 Effect of seed priming, biofertilizer inoculations and nitrogen levels on Nutrient content of wheat

\begin{tabular}{|c|c|c|c|c|c|c|}
\hline \multirow[t]{2}{*}{ Treatment } & \multicolumn{2}{|c|}{$\mathrm{N}$ content $(\%)$} & \multicolumn{2}{|c|}{$P$ content $(\%)$} & \multicolumn{2}{|c|}{ K content (\%) } \\
\hline & Grain & Straw & Grain & \multirow{2}{*}{ Straw } & \multirow{2}{*}{ Grain } & \multirow{2}{*}{ Strav } \\
\hline \multicolumn{4}{|l|}{ Seed priming and inoculation } & & & \\
\hline No seed priming & 1.706 & 0.434 & 0.282 & 0.082 & 0.464 & 1.643 \\
\hline Seed priming with water & 1.723 & 0.448 & 0.283 & 0.082 & 0.465 & 1.656 \\
\hline $\begin{array}{l}\text { Seed priming + Inoculation } \\
\text { with Azotobacter }\end{array}$ & 1.731 & 0.454 & 0.283 & 0.083 & 0.468 & 1.676 \\
\hline $\begin{array}{l}\text { Seed priming + Inoculation } \\
\text { with AM fungi }\end{array}$ & 1.743 & 0.457 & 0.284 & 0.084 & 0.468 & 1.680 \\
\hline $\begin{array}{l}\text { Seed priming + Inoculation } \\
\text { with Biomix }\end{array}$ & 1.758 & 0.460 & 0.286 & 0.083 & 0.469 & 1.682 \\
\hline SEm \pm & 0.014 & 0.009 & 0.003 & 0.001 & 0.001 & 0.010 \\
\hline CD at $5 \%$ & NS & NS & NS & NS & NS & NS \\
\hline \multicolumn{7}{|l|}{ Nitrogen level $\left(\mathrm{kg} \mathrm{ha}^{-1}\right)$} \\
\hline 120 & 1.677 & 0.431 & 0.281 & 0.082 & 0.464 & 1.653 \\
\hline 135 & 1.713 & 0.441 & 0.282 & 0.082 & 0.467 & 1.663 \\
\hline 150 & 1.757 & 0.462 & 0.285 & 0.083 & 0.469 & 1.674 \\
\hline 165 & 1.783 & 0.469 & 0.286 & 0.083 & 0.468 & 1.679 \\
\hline SEm \pm & 0.011 & 0.004 & 0.002 & 0.001 & 0.001 & 0.016 \\
\hline CD at $5 \%$ & 0.033 & 0.013 & NS & NS & NS & NS \\
\hline
\end{tabular}


Table.3 Effect of seed priming, biofertilizer inoculations and nitrogen levels on Nutrient uptake of wheat

\begin{tabular}{|c|c|c|c|c|c|c|c|c|c|}
\hline \multirow[t]{2}{*}{ Treatment } & \multicolumn{3}{|c|}{ N uptake $\left(\mathrm{kg} \mathrm{ha}^{-1}\right)$} & \multicolumn{3}{|c|}{$P$ uptake in $\mathrm{kg} \mathrm{ha}^{-1}$} & \multicolumn{3}{|c|}{ K uptake in $\mathrm{kg} \mathrm{ha}^{-1}$} \\
\hline & Grain & Straw & Total & Grain & Straw & Total & Grain & Straw & Total \\
\hline \multicolumn{10}{|c|}{ Seed priming and inoculation } \\
\hline No seed priming & 62.37 & 24.39 & 86.76 & 10.29 & 4.59 & 14.88 & 16.93 & 92.21 & 109.14 \\
\hline Seed priming with water & 64.69 & 25.82 & 90.51 & 10.60 & 4.72 & 15.32 & 17.46 & 95.55 & 113.01 \\
\hline $\begin{array}{l}\text { Seed priming + } \\
\text { Inoculation with } \\
\text { Azotobacter }\end{array}$ & 67.10 & 27.08 & 94.18 & 10.96 & 4.92 & 15.88 & 18.13 & 99.82 & 117.95 \\
\hline $\begin{array}{l}\text { Seed priming + } \\
\text { Inoculation with AM } \\
\text { fungi }\end{array}$ & 69.15 & 27.35 & 96.50 & 11.26 & 5.05 & 16.31 & 18.57 & 100.58 & 119.15 \\
\hline $\begin{array}{l}\text { Seed priming }+ \\
\text { Inoculation with Biomix }\end{array}$ & 70.34 & 27.75 & 98.09 & 11.43 & 5.01 & 16.44 & 18.73 & 101.39 & 120.12 \\
\hline SEm \pm & 1.33 & 0.68 & 1.46 & 0.23 & 0.05 & 0.24 & 0.32 & 1.58 & 1.57 \\
\hline CD at $5 \%$ & 4.40 & 2.24 & 4.82 & 0.77 & 0.20 & 0.82 & 1.07 & 5.25 & 5.20 \\
\hline \multicolumn{10}{|l|}{ Nitrogen level $\left(\mathrm{kg} \mathrm{ha}^{-1}\right)$} \\
\hline 120 & 60.89 & 23.96 & 84.85 & 10.20 & 4.59 & 14.79 & 16.83 & 92.02 & 108.85 \\
\hline 135 & 64.97 & 25.45 & 90.42 & 10.68 & 4.76 & 15.44 & 17.70 & 96.09 & 113.79 \\
\hline 150 & 69.01 & 27.89 & 96.90 & 11.21 & 5.01 & 16.22 & 18.40 & 101.04 & 119.44 \\
\hline 165 & 72.04 & 28.62 & 100.66 & 11.55 & 5.07 & 16.62 & 18.91 & 102.51 & 121.42 \\
\hline SEm \pm & 0.93 & 0.30 & 1.03 & 0.15 & 0.07 & 0.17 & 0.19 & 1.48 & 1.54 \\
\hline CD at $5 \%$ & 2.70 & 0.87 & 2.99 & 0.42 & 0.19 & 0.48 & 0.54 & 4.29 & 4.47 \\
\hline
\end{tabular}


Phosphorus and potassium content were not influenced significantly by nitrogen levels, however, the improvement in $\mathrm{P}$ and $\mathrm{K}$ uptake due to successive nitrogen levels was significant up to $150 \mathrm{~kg} \mathrm{ha}^{-1}$ (Table 3). This was mainly due to the fact that nutrient uptake followed the yield pattern which increased with increasing level of nitrogen. Similar findings were reported by Ranwa (1997) and Tiwana and Narang (1997).

\section{References}

Bahrani, A., Pourreza, J. and Hagh Joo, M. (2010) Response of winter wheat to co-inoculation with Azotobacter and Arboscular Mycorrhizal Fungi (AMF) under different sources of nitrogen fertilizer. American-Eurasian J. Agric. \& Environ. Sci. 8 (1): 95-103.

Beheraa, U.K. and Rautaray, S.K. (2010) Effect of biofertilizers and chemical fertilizers on productivity and quality parameters of durum wheat (Triticum turgidum) on a Vertisol of Central India. Arch. Agron. Soil Sci. 56 (1): 65-72.

Behl, R.K., Sharma, H., Kumar, V. and Singh, K.P. (2003) Effect of dual inoculation of VAM and Azotobacter chroococcum on above flag leaf characters in wheat. Archives of Agron. and Soil Sci. 49: 25-31.

Gupta, Trilok Chand. (2002) Integrated nutrient management in wheat (Triticum aestivum L.). Ph. D. Thesis submitted to CCS HAU, Hisar.

Jackson, M.L. (1973) Soil chemical analysis.Prentice Hall of India Pvt. Ltd., New Delhi. pp. 214-221.

Jakhar, P. (2004) Effect of planting methods, biofertilizers and nitrogen levels on wheat. MSc. Thesis submitted to CCS HAU, Hisar.

Kachroo, D. and Razdan, R. (2006) Growth, nutrient uptake and yield of wheat
(Triticum aestivum) as influenced by biofertilizers and nitrogen. Indian $J$. Agron. 51 (1): 37-39.

Kader, M.A., Milan, M.H. and Hoque, M.S. (2002) Effects of Azotobacter innoculant on the yield and nitrogen uptake by wheat. Online J. Bio. Sci. 2 (4): 259-261.

Kaur, H., Ram, H., Sikka, R. and Kaur, H. (2016) Productivity, agronomic efficiency and quality of bread wheat [Triticum aestivum (L.)] cultivars in relation to nitrogen. IJAEB: 9(1): 101106.

Lindner, R.C. (1944) Rapid analytical methods for some of the more common inorganic constituents of plant tissues. Plant Physiology, 19, 76-86.

Milošević, N., Tintor, B. and Cvijanović, G. (2012) Effect of inoculation with Azotobacter chroococcum on wheat yield and seed quality. International conference: conventional and molecular breeding of field and vegetable crops. Romanian Biotechnological Letters. 17(3): 73527357.

Narolia, R.S., Meena, H., Singh, P., Meena, B.S. and Ram, B. (2016) Effect of irrigation scheduling and nutrient management on productivity, profitability and nutrient uptake of wheat (Triticum aestivum) grown under zero-tilled condition in southeastern Rajasthan. Indian J. Agron. 61 (1): 53-58.

Narula, N., Kumar, V., Singh, B., Bhatia, R. and Lakshminarayana, K. (2005) Impact of biofertilizers on grain yield in spring wheat under varying fertility conditions and wheat-cotton rotation. Archives Agron. Soil Sci. 51(1): 79-89.

Nishant, Vivek; Singh, V., Sharma, D.K. and Raju (2016) Influence of organic and inorganic sources on nutrient uptake 
and yield of wheat (Triticum aestivum 1.) in western Uttar pradesh. Prog. Agric. 16 (2): 223-228.

Pandey, A.K., Kureel, R.S., Shukla, U.N., Singh. S., Mishra, M.L. and Kumar, J. (2014). Effect of nitrogen doses and scheduling on yield, quality and uptake of NPK under late sown wheat. Bioinfolet, 11 (2A): 284-288.

Patel, C.B., Singh, R.S., Yadav, M.K., Singh, S.K., Singh, M.K., Singh, K.K. and Mall, R.K. (2012) Response of different wheat (Triticum aestivum L. emend Fiori \& Paol.) genotypes to various nitrogen levels under late sown conditions of Eastern Uttar pradesh. Env. \& Ecology, 30 (3C): 1192-1196.

Ranwa, R.S. (1997) Studies on integrated nutrient management with vermicompost in wheat. $\mathrm{Ph}$. D. Thesis submitted to CCS HAU, Hisar.

Richards, L.A. (1954) Diagnosis and improvement of saline and alkali soils; USDA Hand Book No. 60, United State Salinity Laboratory.

Saber, Z., Pirdashti, H., Esmaeili, M., Abbasian, A. and Heidarzadeh, A. (2012) Response of wheat growth parameters to co-inoculation of plant growth promoting rhizobacteria (PGPR) and different levels of inorganic nitrogen and phosphorus. World Appl. Sci. J. 16 (2): 213-219.
Singhal, S.K., Sharma, V.K. and Singh, R.D. (2012) Effect of inorganic and biofertilizers (vam and psb) on yield of maize and wheat cropping sequence and soil fertility. Indian j. agric. res. 46 (2): 167-172.

Singh, N.K., Choudhary, F.K. and Patel, D.B. (2013) Effectiveness of Azotobacter bio-innoculant for wheat grown under dry land condition. J. Env. Biology, 34: 927-932.

Suri, V.K. and Choudhary, A.K. (2010) Comparative performance of vamycorrhizal (vam) fungi and applied phosphorus in wheat under controlled environment in a phosphorus deficient acid alfisol. Prog. Agile. 10 (1): 23-28.

Sushila, R. and Giri, G. (2000) Influence of FYM, nitrogen and biofertilizers on microbial population, dry matter accumulation and nutrient uptake of wheat under limited water supply. Biofert. Newsl. 7: 22-26.

Tiwana, U.S. and Narang, R.S. (1997) Crop productivity and soil nitrate nitrogen change in rice-wheat cropping sequence grown under maximum yield fertilization. Indian J. Agron. 42(4): 559-563.

Venkatashwarlu B (2008). Role of biofertilizers in organic farming: Organic farming in rain fed agriculture: Central institute for dry land agriculture, Hyderabad. pp.85-95.

\section{How to cite this article:}

Bishnupriya Patra and Jagdev Singh. 2018. Effect of Priming, Biofertilizers and Nitrogen Levels on Yield and Nutrient Uptake by Wheat. Int.J.Curr.Microbiol.App.Sci. 7(07): 14111417. doi: https://doi.org/10.20546/ijcmas.2018.707.168 